\title{
見透し内マイクロ波伝搬におけるシンチ レーション・フェージング
}

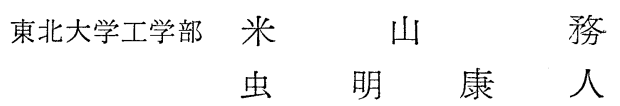

\begin{abstract}
大気中に打けるマイクロ波伝搬に見られるシンチレーション・フェージングの問題を, 誘電率のゆらぎに結びつけて解析している，そのさい，ゆらぎは統計的に異方性であると して，その異方性とフェージングの間の関係を吟味することに重点が括かれている．また 誘電率のゆらぎの相関々数を種々変光た場合についても, それがフェージングにおよぼす 影響を論じている。
\end{abstract}

レーダシステムや追尾装置の高度の発達にともない, これらに使用されるマイクロ波のシンチレーション・フ エージングが, 装置の究極の精度に影響する重要な因子 として注目されるようになってから，すでに十数年を経 ている.

シンチレーション・フェージングの成因は, 伝搬路上 に存在する誘電率のランダムな㠴らぎによってマイクロ 波が散乱される結果であると考学られて和り，ここに理 論的には乱流理論に立脚した確率論的考察が要求され る.このことからも明らかなように, フェージングの理 論的解析では，まず誘電率のゆらぎによるマイクロ波の 散乱現象を明らかにし，その後に，ゆらぎのランダムな 性質についての考察が加光られなければならない。

マイクロ波の散乱の解析については使用される数学的 方法に応じて, 幾何光学的取扱い, 散乱断面積による取

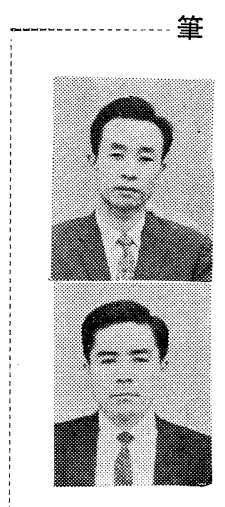

\section{者紹介}

权や去加和昭和 34 年, 東北大学工 米山務 学部通信工学科を卒業. 引続き同大学工学研究科でアンテナおよびミ リ波伝送系の研究従事してきたが, 最近は 主として Radio star あるいは大気中マイ クロ波伝搬のシンキレーション・フェージン グについて理論的な計算を行なっている. む比市与昭和 19 年, 東北帝国大 虫明康人学通信工学科孝卒業. さ ら飞同 24 年大学院特別研究生を修了後, 東 北大学助教授となる. 昭和 29 年, 工学博士 の学位を受け, 渡米してオハイオ州立大学ア ンテナ研究所研究員となり, 同 31 年帰国. 昭和 35 年 4 月以来, 東北大学工学部教授々 して通信工学第 3 講座 (高周波工学) を担任

" Scintillation Fading in Line-of-sight Microwave Proagation" By Tsukasa Yoneyama and Yasuto Mushiake.

$26(410)$
扱い，牤よび波動方程式を直接解く方法に分けて考光ら れる. 幾何光学的取扱いは伝搬路上の誘電率のゆらぎを 光路長の変動に結びつけ, これによって受信波の位相の 変動を求めようとするものである. この方法は伝搬距離 が比較的短 $<$, 誘電率のゆらぎの平均的な拡がりが第 1 フレネルゾーンにくらべて大きい場合に，適用が可能と なる1).

これに対し散乱断面積による取扱いは伝搬距離が十分 大きくなり，第 1 フレネルヅーンの中に多数の誘電率の ゆらぎが存在すると考光らるときに有効であり，この場 合にはゆらぎを点散乱体と考光，これから散乱される incoherent な波を合成して,全体としての散乱電磁界を 決定する ${ }^{2)}$.

一方, 波動方程式を直接解く方法では Born 近似， 女 るいは Rytov 近似を使って散乱電磁界を積分の形で求 め，これをもとにして計算を進める3,4)。この方法では 伝搬路の長さに対する制限はなく, 特別な場合として伝 搬距離が十分短いとさには幾何光学的に得られた結果に 一致し, また伝搬距離を十分長くすれば, 散乱断面積を 使って得られた結果に一致する. この意味で, 波動方程 式から直接散乱電磁界を求める方法は一般的であり, 統 一的解法といえるわけで女るが，㐫の解析の過程がやや. 複雑になることは避㿥なないことである.

以上の電磁現象的な問題に対し, 誘電率のゆらぎの統 計的な性質については, いまだ判然としない点が多いよ らである.このような疑点の解明は, 乱流理論の今後の 発展にまたなければならないが，逆に電波伝搬について の測定技術が大気の乱流現象の研究に対して，1つの有 効な手段を提供しているのが現状であり, 大気中の誘電 
率のゆらぎの統計的性質は大気乱流論と電波伝搬の研究 の相ともなった成果によって，初めて明らかになるもの と思われる。

したがって, 誘電率のゆらぎについて, その性質を適 当に仮定し，その仮定のもとにフェージングの定量的評 価を行ない, 実験との対比に沶いて最初の仮定の妥当性 を吟味するという cut and try な方法も容認せざるを えないのである。

そしてシンチレーション・フェージングを伝搬路上の 誘電率のゆらぎとの関係に和いて論じたこれまでの大部 分の研究では，ゆらぎは統計的に均質かつ等方性である といら理想化された状態で考察されている.しかしなが ら、ゆらぎについてのこのよ5な仮定が実際の大気につ いて，そのまま成立つと考劣ることは困難で，たとえば ゆらざの強さは高度とともに減少していることが実測の 結果明らかにされている5)。 また大気に対する重力の影 響を考慮すれば，垂直方向が特別な軸としてえらばれて いることがわかり，ゆらぎの構造は軸対称な異方性とな $ろ^{6)}$.

このように大気中の誘電率のゆらぎについては均質性 の仮定も等方性の仮定も認めがたいものであるが，ほと んど水平な見透し内伝搬路のみに限れば，ゆらぎは統計 的沟質であるとしてよいであろう。

以上のような考察から，実際の見透し内伝搬路上の誘 電率のゆらぎの状態を比較的よく近似しているモデルと して，ここでは均質ではあるが統計的に異方性であるゆ らぎを仮定し, その異方性の程度がマイクロ波のシンチ レーション・フェージングに拈よぼす影響について調べ ることにする，解析にあたっては，波動方程式を直接 Rytov 近似を使って解き，マイクロ波の振幅和よび位 相の変動の 2 㐘平均値を求める.

な特計算を進めるにあたって，フェージングの大きさ と誘電率のゆらぎを関係づけるものとして, ゆらぎの相 関々数についての知識が必要となるが，これは前述した ように，大気の乱流現象の十分な解明にまたなければな らず，通常は適当な関数形を仮定してその代用としてい る.

見透し内伝搬路に挡けるシンチレーション・フェージ

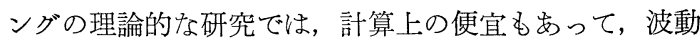
方程式を直接解く方法によるときにはほとんど Gauss 形相関々数をとっているのが通例である ${ }^{3,4)}$. 本論でも, ゆらぎの相関々数としては異方性を考慮した Gauss 形 を仮定しているが，さらに相関々数の関数形とフェージ ングの特性の間の関係について吟味するために, Bessel 形相関々数を使った計算も合わせて行なっている.

このようなシンチレーション・フェージングについて
第1図 受信波のベクト ル図とその等確率 曲線

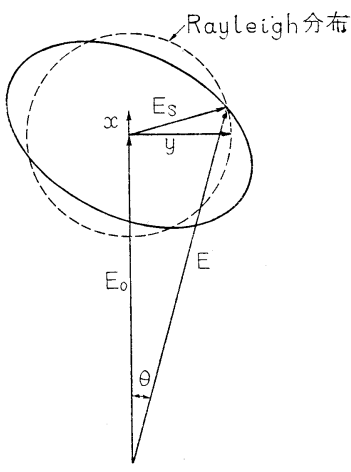

の実測結果も二，三報告されてはいるが7,8)，ここでの 計算結果を積極的に裏づけるにたるデータはいをだそし いようである. それで, 理論的な計算結果のみに限って 一応ここに報告する次第である。

な誩本論での解析方法, 括よび得られた諸結果は, 水 中音響学, 電離層物理学, あるいは天文学に和ける類似 の問題にただちに適用でさ，とくに Radio star または 人工衛星からの電波のフェージングを観測し，これを電 離層内の等価誘電率のゆらぎに結びつケて, 逆に電離層 の微細構造を推定しようとする最近の試みに有効に応用 されていることを付記して特く ${ }^{9,10)}$.

\section{1. 受信波の確率分布についての概略}

以後の各節に打汀る論点を明確にする意味から, ここ で見透し内マイクロ波伝搬に拉ける受信波について，卡 の確率分布の定性的な考察を行なって执く.

第 1 図は受信波をべクトル図で示したものであるが， $E_{0}$ は送受信点間を直接伝搬した一次波を表わし， $E_{S}$ は 伝搬路上にある誘電率のゆらざによって散乱された多数 の波を合成したものである. 受信波 $E$ は一次波 $E_{0}$ と 散乱波 $E_{s}$ のベクトル和であり，そのランダムな変動は 散乱波によるものである。さ㐫らん実際の伝搬路にあって は一次波の変動も無視はできないのであるが，ここでは 考察の対象をシンチレーション・フェージングに限り, したがって一次波は不変であるとする。

さて，散乱波を位相的に直角な $x$ 打よび $y$ なる 2 成 分に分解すれば，確率論の中心極限定理により，その分 布関数は次式で与えられる.

$$
\begin{aligned}
& P(x, y)=\frac{1}{2 \pi \sigma_{x} \sigma_{y} \sqrt{1-\rho^{2}}} \\
& \exp \left\{-\frac{1}{2\left(1-\rho^{2}\right)}\left(\frac{x^{2}}{\sigma_{x}^{2}}-2 \rho \frac{x y}{\sigma_{x} \sigma_{y}}+\frac{y^{2}}{\sigma_{y}^{2}}\right)\right\}
\end{aligned}
$$

ここに $\sigma_{x}^{2}$ および $\sigma_{y}^{2}$ はとれぞれ $x$ 打よび $y$ の分散で あり, $\rho$ は $x$ と $y$ の間の相関係数を表わす. (1) 式より 散乱波の等確率曲線は 


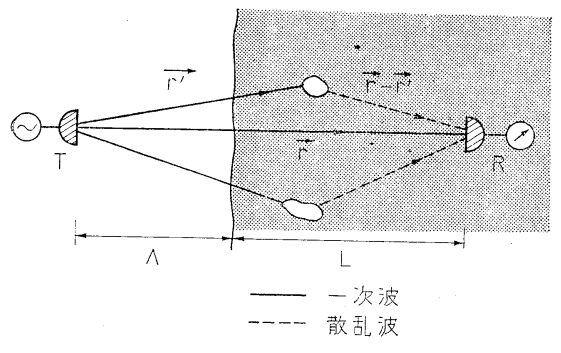

第 2 図伝搬路のモデル

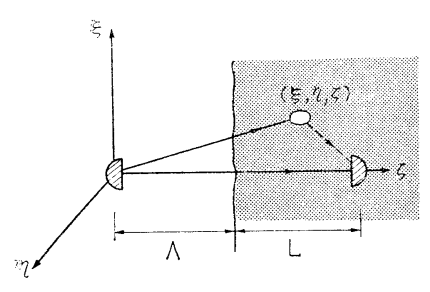

第 3 図座標系

$$
\frac{x^{2}}{\sigma_{x}^{2}}-2 \rho \frac{x y}{\sigma_{x} \sigma_{y}}+\frac{y^{2}}{\sigma_{y}^{2}}=\text { const. }
$$

なる二次曲線となる。

(2) 式で $x$ と $y$ の分散が等しく, かつその間に相関 がないと仮定すれば，等確率曲線は円となり，そのとき には散乱波はいわゆる Rayleigh 分布に従了。一次波に Rayleigh 分布する散乱波が重畳された場合の合成波の 確率分布については Norton 等による研究がある11.

しかしながら, 骞際の伝搬路にあっては $x$ と $y$ の分 散は一般には等しくなく、またそれらの間にも相関が存 在することが知られている3). したがって，このような 一般的な場合には散乱波の等確率曲線は第 1 図に示すよ うな棈円となる。一次波と棈円分布する散乱波を合成し て得られる波形の確率分布については，その計算はかな り複雑となるが，とくに相関係数 $\rho$ を零にした場合の例 が Beckmann によって報告されている ${ }^{12)}$.

さて, 一次波の振幅を $A_{0}$, 受信波の振幅を $A$ とする そき

$$
Q=\log \left(A / A_{0}\right)
$$

なる量を受信波の対数振幅とよぶことにする。ぬた一次 波に対する受信波の位相を日で表わす。これらの量は散 乱波が棈円分布にしたがって変化するにつれて，ランダ ムに変動し, その平均值は零である. 以下に和いて, 対 数振幅执よび位相の変動の 2 乗平均值を伝搬路の長さ, 使用周波数, 特よび誘電率のゆらぎの統計的性質に関連 づけて解析的に求めるが，その值が 1 にくらべて小さい 場合には, 対数振幅の変動の 2 乗平均値は $\sigma_{x}^{2} に$, また 位相の変動の 2 乗平均值は $\sigma_{y}^{2}$ にそれぞれ等しくなるの である.

\section{2. 基本式の誘導}

第 2 図は伝搬路のモデルである。送信点 $T$ から大気 層をでの距離を $A$ で示すが，これを無限大にすれば Radio star のモデルとなり，平面波が大気層に入射し て来ることになる.この伝搬モードを Plane wave mode とよぶことにする。これに対し $\Lambda$ を零にすれば，送受 信点ともに大気中にあることになり, 通常の Radio relay link に対応する.

これは Spherical wave mode とよばれ, 送信点から は球面波が伝搬して行く.

さて, 誘電率のゆらぎのある媒質中にあっては, つぎ の波動方程式が成立する.

$$
\nabla^{2} E+k^{2}(1+\Delta \varepsilon) E=0
$$

ここに $\Delta \varepsilon$ は誘電率のゆらぎを表わす。ここで

$$
\psi=\log \left(E / E_{0}\right)
$$

と䂦けば，第 1 図を参照して，その実数部が対数振幅の 変動を，またその虚数部が位相の変動を表わしているこ とがわかる（5) 式を（4）式に代入し，かつ1波長につ いての電界のランダムな変動が 1 にくらべて十分小さい と仮定すれば

$$
\nabla^{2}\left(E_{0} \psi\right)+k^{2}\left(E_{0} \psi\right)=-k^{2} \Delta \varepsilon E_{0}
$$

を得る.（6）式は非斉次の波動方程式であり，その解は

$$
\psi \overrightarrow{(r)}=\frac{k^{2}}{4 \pi E_{0}(\vec{r})} \int_{v} \Delta \varepsilon \overrightarrow{\left(r^{\prime}\right)} E_{0}\left(\vec{r}^{\prime}\right) \frac{e^{-j k\left|\vec{r}-r^{\prime}\right|}}{\overrightarrow{\mid r}-\vec{r} \mid} d v^{\prime}
$$

となる、ここに $\vec{r}$ 特よび $\overrightarrow{r^{\prime}}$ はそれぞれ送信点を原点に えらんだときの受信点特よび誘電率のゆらぎの位置べク トルであり, 積分領域 $V$ は送受信点間にある大気層全 体にわたるものとする.

一次波 $E_{0}$ は送信点からの球面波であるから

$$
E_{0}(\vec{r})=\frac{e^{-j k|\vec{r}|}}{|\vec{r}|}
$$

と置くことがでさ，これを(7) 式に代入し，その結果を 実数部执よび虚数部に分解することにより

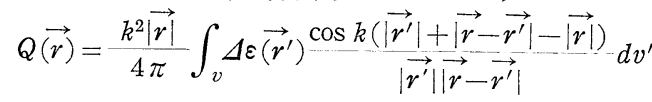

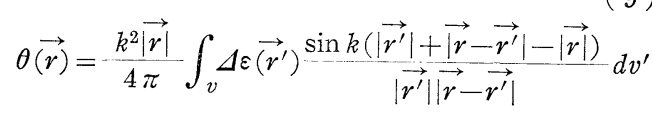

を得る.ここに $Q(\vec{r})$ 牤よび $\theta \overrightarrow{(\vec{r})}$ は, それぞれ対数振 幅括よび位相の変動である。

ここで第 3 図に示すように座標系を定め, 送信点を原 点にとり， $\zeta$ 軸上原点より $\zeta=L+\Lambda$ なる距離に受信点 を置くことにする、この座標系を使って（9）式拈よび (10) 式を Fresnel 近似すれば 


$$
\begin{aligned}
Q & =\frac{k}{2} \int_{\Lambda}^{\Lambda+L} d \zeta \iint_{-\infty}^{+\infty} d \xi d \eta \Delta \varepsilon(\xi, \eta, \zeta) \\
& \times \Phi_{2}\left[\frac{\zeta(\Lambda+L-\zeta)}{k(\Lambda+L)}, \rho\right] \\
\theta & =\frac{k}{2} \int_{\Lambda}^{\Lambda+L} d \zeta \iint_{-\infty}^{+\infty} d \xi d \eta \Delta \varepsilon(\xi, \eta, \zeta) \\
& \times \Phi_{1}\left[\frac{\zeta(\Lambda+L-\zeta)}{k(\Lambda+L)}, \rho\right]
\end{aligned}
$$

を得る.ここに関数 $\Phi_{1}(\sigma, \rho)$ 特よび $\Phi_{2}(\sigma, \rho)$ はそれぞ れ次式で定義されるものである.

$$
\begin{aligned}
& \Phi_{1}(\sigma, \rho)=\frac{1}{2 \pi \sigma} \sin \frac{\rho^{2}}{2 \sigma} \\
& \Phi_{2}(\sigma, \rho)=\frac{1}{2 \pi \sigma} \cos \frac{\rho^{2}}{2 \sigma}
\end{aligned}
$$

ただし

$$
\rho^{2}=\xi^{2}+\eta^{2}
$$

である.（11）式抢よび (12) 式が以後の計算の基礎とな る式である.

\section{3. 対数振幅および位相の変動の 2 乗平均值}

(11) 式特よび (12) 式から, 誘電率のゆらぎを均質と 仮定することにより, 対数振幅および位相の変動の 2 乗 平均值はつぎのように求まる.

$$
\begin{aligned}
\left\langle Q^{2}\right\rangle= & \frac{k^{2}}{4}\left\langle\Delta \varepsilon^{2}\right\rangle \iint_{\Lambda}^{\Lambda+L} d \zeta_{1} d \zeta_{2} \\
& \iiint \int_{-\infty}^{+\infty} d \xi_{1} d \xi_{2} d \eta_{1} d \eta_{2} C\left(\xi_{1}-\xi_{2}, \eta_{1}-\eta_{2}, \zeta_{1}-\zeta_{2}\right) \\
& \times \Phi_{2}\left[\frac{\zeta_{1}\left(\Lambda+L-\zeta_{1}\right)}{k(\Lambda+L)}, \rho_{1}\right] \Phi_{2}\left[\frac{\zeta_{2}\left(\Lambda+L-\zeta_{2}\right)}{k(\Lambda+L)}, \rho_{2}\right] \\
\left\langle\theta^{2}\right\rangle= & \frac{k^{2}}{4}\left\langle\Delta \varepsilon^{2}\right\rangle \iint_{\Lambda}^{\Lambda+L} d \zeta_{1} d \zeta_{2} \\
& \iiint \int_{-\infty}^{+\infty} d \xi_{1} d \xi_{2} d \eta_{1} d \eta_{2} C\left(\xi_{1}-\xi_{2}, \eta_{1}-\eta_{2}, \zeta_{1}-\zeta_{2}\right) \\
& \times \Phi_{1}\left[\frac{\zeta_{1}\left(\Lambda+L-\zeta_{1}\right)}{k(\Lambda+L)}, \rho_{1}\right] \Phi_{1}\left[\frac{\zeta_{2}\left(\Lambda+L-\zeta_{2}\right)}{k(\Lambda+L)}, \rho_{2}\right]
\end{aligned}
$$

ここに〈 $\left.\Delta \varepsilon^{2}\right\rangle$ 拉よび $C\left(\xi_{1}-\xi_{2}, \eta_{1}-\eta_{2}, \zeta_{1}-\zeta_{2}\right)$ はそれ ぞれ誘電率のゆらぎの 2 乗平均值叔よび相関々数であ る.つぎに

相対座標:

$$
\xi=\xi_{1}-\xi_{2}, \quad \eta=\eta_{1}-\eta_{2}, \quad \zeta=\zeta_{1}-\zeta_{2}
$$

および重心座標 :

$$
x=\frac{1}{2}\left(\xi_{1}+\xi_{2}\right), \quad y=\frac{1}{2}\left(\eta+\eta_{2}\right), \quad z=\frac{1}{2}\left(\zeta_{1}+\zeta_{2}\right)
$$

を導入して，(16) 式および (17) 式を書きかえれば

$$
\left\langle Q^{2}\right\rangle=\frac{k^{2}}{4}\left\langle\Delta \varepsilon^{2}\right\rangle \int_{\Lambda}^{\Lambda+L} d z
$$

$$
\begin{aligned}
& \iiint \iint_{-\infty}^{+\infty} d \xi d \eta d \zeta d x d y C(\xi, \eta, \zeta) \\
& \times \Phi_{2}\left[\frac{\left(z+\frac{1}{2} \zeta\right)\left(\Lambda+L-z-\frac{1}{2} \zeta\right)}{k(\Lambda+L)},\right. \\
& \left.\sqrt{\left(x+\frac{1}{2} \xi\right)^{2}+\left(y+\frac{1}{2} \eta\right)^{2}}\right] \\
& \times \Phi_{2}\left[\frac{\left(z-\frac{1}{2} \zeta\right)\left(\Lambda+L-z+\frac{1}{2} \zeta\right)}{k(\Lambda+L)},\right. \\
& \left.\sqrt{\left(x-\frac{1}{2} \xi\right)^{2}+\left(y-\frac{1}{2} \eta\right)^{2}}\right] \\
& \langle\theta\rangle^{2}=\frac{k^{2}}{4}\left\langle\Delta \varepsilon^{2}\right\rangle \int_{\Lambda}^{\Lambda+L} d z \\
& \iiint \iint_{-\infty}^{+\infty} d \xi d \eta d \zeta d x d y C(\xi, \eta, \zeta) \\
& \times \Phi_{1}\left[\frac{\left(z+\frac{1}{2} \zeta\right)\left(\Lambda+L-z-\frac{1}{2} \zeta\right)}{k(\Lambda+L)},\right. \\
& \left.\sqrt{\left(x+\frac{1}{2} \xi\right)^{2}+\left(y+\frac{1}{2} \eta\right)^{2}}\right] \\
& \times \Phi_{1}\left[\frac{\left(z-\frac{1}{2} \zeta\right)\left(\Lambda+L-z+\frac{1}{2} \zeta\right)}{k(\Lambda+L)},\right. \\
& \left.\sqrt{\left(x-\frac{1}{2} \xi\right)^{2}+\left(y-\frac{1}{2} \eta\right)^{2}}\right]
\end{aligned}
$$

となる。（20）式特よび（21）式に特いて，x拈よび $y$ に ついての積分を遂行すれば，つぎのような結果を得る。

$$
\left.\begin{array}{l}
\left\langle Q^{2}\right\rangle \\
\left\langle\theta^{2}\right\rangle
\end{array}\right\}=\frac{k^{2}}{8}\left\langle\Delta \varepsilon^{2}\right\rangle\left(I_{1} \mp I_{2}\right)
$$

ここに $I_{1}$ 叔よび $I_{2}$ は，それぞれつぎの積分で与えら れる.

$$
\begin{gathered}
I_{1}=\int_{\Lambda}^{\Lambda+L} d z \iiint_{-\infty}^{+\infty} d \xi d \zeta C(\xi, \eta, \zeta) \Phi_{1}\left[\frac{\zeta(\Lambda+L-2 z)}{k(\Lambda+L)}, \rho\right] \\
I_{2}=\int_{\Lambda}^{\Lambda+I} d z \iiint_{-\infty}^{+\infty} d \xi d \eta d \zeta C(\xi, \eta, \zeta) \\
\Phi_{1}\left[\frac{2 z(\Lambda+L-z)}{k(\Lambda+L)}, \rho\right]
\end{gathered}
$$

ただし

$$
\rho^{2}=\xi^{2}+\eta^{2}
$$

である。

結局, 誘電率のゆらぎの相関々数を適当に仮定して, (23) 式执よび (24) 式の積分を計算すればよいわけで女 るが，(23) 式に与えられる $I_{1}$ にいててはきわめて簡単 な結果が得られる.すなわち大気中に特ける誘電率のゆ らぎの大きさは数十メートルの程度であるから，これは マイクロ波の波長にくらべて十分大きく，このとき， $I_{1}$ は付録 [I] に示すように, Stationary phase method を使って計算することができ

(413) 29, 


$$
I_{1}=2 L l_{\zeta}
$$

となる。ここに $l_{\zeta}$ は

$$
l_{\zeta}=\int_{0}^{\infty} C(0,0, \zeta) d \zeta
$$

で与えられ， $\zeta$ 軸方向に怙ける誘電率のゆらぎの大きさ を表わするので，これをゆらぎの相関距離とよぶことに する.

つざに $(24)$ 式の $I_{2}$ を計算するには誘電率のゆらぎ の相関々数について, 具体的な関数形を仮定しなければ ならない。しかしながら，速度場の乱流から誘電率のゆ らぎが発生する機構汇ついてはいまだ疑問の点もあり， したがってその相関々数についても統一的な結論には到 達していないのである。そこで，ここでは一応，見透し 内マイクロ波伝搬のフェージングの研究で広く使われて いる Gauss 形相関々数を仮定し, さらに異方性を導入 ᄂて

$$
C(\xi, \eta, \zeta)=\exp \left(-\frac{p^{2} \xi^{2}+q^{2} \eta^{2}+\zeta^{2}}{l^{2}}\right)
$$

そおくことにする，ここにゃ拈よび $q$ は誘電率のゆらぎ の異方性の程度を表わす parameter である。な挔相関 関数をBessel 形にした場合については第 6 節で吟味す ることにする.

(28) 式の相関々数を（24）式に代入し， $\xi ＼eta \eta$ 抢よび とに関する積分を遂行し，かつ $z$ につては適当な変数 変換を施して変形すれば，(24）式はつぎのような楕円 積分に帰着される。

$$
\begin{aligned}
& I_{2}=\frac{\sqrt{\pi}}{2} \frac{k l^{3}}{p q} I_{m} \\
& {\left[\int_{-1}^{1} \frac{d u}{\sqrt{\left.x_{p}-\frac{L u^{2}+2 \Lambda u-\Lambda}{L+\Lambda}\right)\left(x_{q}-\frac{L u^{2}+2 \Lambda u-\Lambda}{L+\Lambda}\right)}}\right]}
\end{aligned}
$$

ここに

$$
\begin{aligned}
& x_{p}=1-j \frac{4}{p^{2} D} \\
& x_{q}=1-j \frac{4}{q^{2} D}
\end{aligned}
$$

でありまた $D$ は Scattering parameter とよばれ次 式で定義される.

$$
D=\frac{4 L}{k l^{2}}
$$

ここで前に返って，II を与光る (26) 式は任意の相関 関数に対して成立つものであるが，とくに（28）式の Gauss 形相関々数を考学れば

$$
I_{1}=\sqrt{\pi} L l
$$

となる。（29）式就よ゙（33）式を（22）式代入すれば, 対数振幅招よび位相の変動の 2 乗平均值は

$30(414)$

$$
\left.\begin{array}{c}
\left\langle Q^{2}\right\rangle \\
\left\langle\theta^{2}\right\rangle
\end{array}\right\}=\sqrt{\pi} \frac{k^{3} l^{3}}{32}\left\langle\Delta \varepsilon^{2}\right\rangle\left[D \mp \frac{4}{p q} I_{m}\left\{F\left(x_{p}, x_{q} ; \Lambda\right)\right\}\right]
$$

となる.ここに

$$
\begin{aligned}
& F\left(x_{p}, x_{q} ; \Lambda\right)=\frac{1}{2} \\
& \times \int_{-1}^{1} \frac{d u}{\sqrt{\left(x_{p}-\frac{L u^{2}+2 \Lambda u-\Lambda}{L+\Lambda}\right)\left(x_{q}-\frac{L u^{2}+2 \Lambda u-\Lambda}{L+\Lambda}\right)}}
\end{aligned}
$$

である、したがって (35) 式の棈円積分を数值計算する ことが，ここでの問題となる。

\section{Plane wave mode の場合について13)}

Plane wave mode は送信点が大気層上, 十分な高度 にある場合を理想化したもので, Radio star からの放 射電磁波, まるいは人工衛星からの信号を地上で受信し

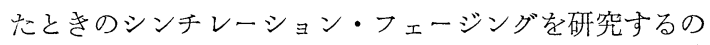
に適している.

第 4 図はそのモデル図である。まず（35）式に捺いて 送信点と大気層の間の距離 $A$ 無限大を置けば，楕円 積分はつぎのような二次無理式の積分となる。

$$
F\left(x_{p}, x_{\mathrm{q}} ; \infty\right)=\frac{1}{2} \int_{-1}^{1} \frac{d u}{\sqrt{\left(x_{p}+1-2 u\right)\left(x_{q}+1-2 u\right)}}
$$

（36）式の積分は容易に遂行することができ，その結果， 次式得る.

$$
\begin{aligned}
I_{m} & \left\{F\left(x_{p}, x_{q} ; \infty\right)\right\} \\
& =\frac{1}{2} \tan ^{-1} \frac{p q D}{\left[\left\{\sqrt{ }\left(p^{4} D^{2}+1\right)+1\right\}\left\{\sqrt{ }\left(q^{4} D^{2}+1\right)+1\right\}\right]^{1 / 2}}
\end{aligned}
$$

これょり (34) 式を参照して, 対数振幅拉よび位相の変 動の 2 乗平均值はつぎのように求まる.

$$
\begin{aligned}
& \left.\begin{array}{l}
\left\langle Q^{2}\right\rangle \\
\left\langle\theta^{2}\right\rangle
\end{array}\right\}=\sqrt{\pi} \frac{k^{3} l^{3}}{32}\left\langle\Delta \varepsilon^{2}\right\rangle\left[D \mp-\frac{2}{p q} \tan ^{-1}\right. \\
& \left.\times \frac{p q D}{\left[\left\{\sqrt{ }\left(p^{4} D^{2}+1\right)+1\right\}\left\{\sqrt{ }\left(q^{4} D^{2}+1\right)+1\right\}\right]^{1 / 2}}\right]
\end{aligned}
$$

ここで，とくにp新よび $q$ を1亿等しいと就けば (38) 式は

$$
\left.\begin{array}{l}
\left\langle Q^{2}\right\rangle \\
\left\langle\theta^{2}\right\rangle
\end{array}\right\}=\sqrt{\pi} \frac{k^{3} l^{3}}{32}\left\langle\Delta \varepsilon^{2}\right\rangle\left[D \mp \tan ^{-1} D\right]
$$

となる、これは Chernov ${ }^{3}$ が誘電率のゆらぎを等方性と 仮定し, Gauss 形相関々数を用いて誘導した結果に一致 する.

つぎに Scattering parameter $D$ が小さい場合, 括よ び大きい場合について，(38) 式の近似式を求める. ず（38）式に抽いて $D$ が十分小さいとすれば，対数振 幅の変動および位相の変動の 2 乗平均值はそれぞれつぎ

$$
\text { テレビジョン }
$$




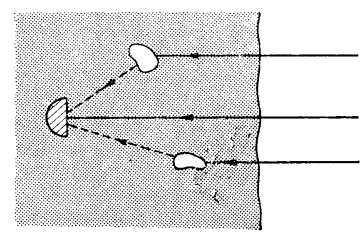

第 4 図 Plane wave mode

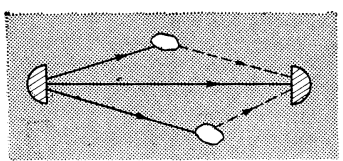

第 6 図 Spherical wave mode

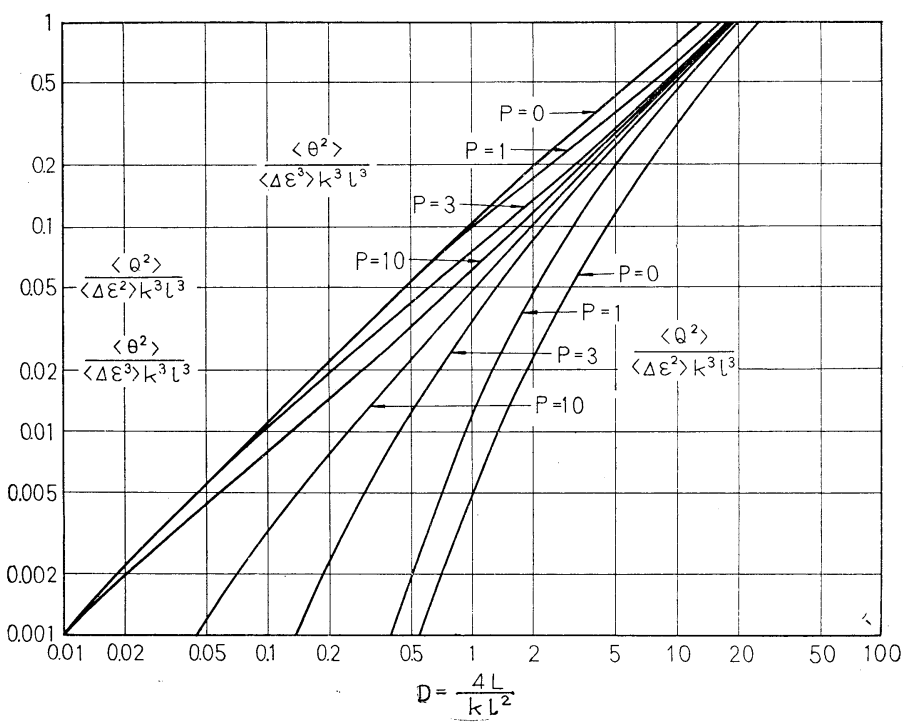

第 5 図 Plane wave mode における対数振幅および位相の変動 の 2 乗平均值
のように近似される.

$$
\begin{aligned}
& \left\langle Q^{2}\right\rangle=\sqrt{\pi} \frac{k^{3} l^{3}}{32}\left\langle\Delta \varepsilon^{2}\right\rangle\left\{\frac{\left(p^{2}-q^{2}\right)^{2}}{8}+\frac{p^{2} q^{2}}{3}\right\} D^{3} \\
& \left\langle\theta^{2}\right\rangle=\sqrt{\pi} \frac{k^{3} l^{3}}{16}\left\langle\Delta \varepsilon^{2}\right\rangle D
\end{aligned}
$$

これらの式から明らかなように Scattering parameter $D$ が十分小さい範囲では, 位相の変動に比較して振幅の 変動は無視しうる程度である.なお (41) 式の位相の変 動は幾何光学的取扱いによっても容易に導くことができ る1). これに対し $D$ が十分大きい場合には，(38) 式は

$$
\left.\begin{array}{l}
\left\langle Q^{2}\right\rangle \\
\left\langle\theta^{2}\right\rangle
\end{array}\right\}=\sqrt{\pi} \frac{k^{3} l^{3}}{32}\left\langle\Delta \varepsilon^{2}\right\rangle D
$$

となる.この近似式は誘電率のゆらぎを, 一定の散乱断 面積をもった点散乱体と考光，それによって散乱される “電磁波を合成しても得ることができる2). (38) 式の数值 計算結果を第 5 図に示す，実際の大気では，誘電率のゆ らぎは垂直方向の久に異方性を有すると考えられるか ら，qを1と狺き， $p$ を異方性の parameter にとって 四示してある。図からただちに知られるように, Scattrering parameter $D$ が小さい場合，および大きい場合 には，ゆらぎの異方性の影響はあまり顕著ではなく，そ の中間の領域，すなわちゆらぎによる散乱が Fresnel scattering $(D \ll 1)$ から Fraunhofer scattering $(D \gg 1)$ に移る過渡領域で最も著しい異方性の効果が見られる. このことはシンチレーション・フェージングの問題を波 動方程式を使って解いて, はじめて明らかにされるので 女る。

\section{Spherical wave mode の場合について ${ }^{14)}$}

第 6 図は Spherical wave mode のモデル図である. この場合には，送受信点がともに大気中にあり，Radio relay link に相当したもので女る.

さて，(35) 式で $\Lambda$ を零とすれば

$$
F\left(x_{p}, x_{q} ; 0\right)=\int_{0}^{1} \frac{d u}{\sqrt{\left(x_{p}-u^{2}\right)\left(x_{q}-u^{2}\right)}}
$$

を得る.（43）式の楕円積分は，一般には母数が複素数 となるので, 数表の利用も限られる。 したがってその数 值計算が問題となるが，ここではこれを初等関数で近似 乙，その近似式を使って数值計算を行なうという方法を そった. 近似の手続の詳細は付録にゆずり, 以下にその 結果のみを簡単にのべる (付録-II 参照).

まず $(43)$ 式が $x_{p}$ と $x_{q}$ に関して対称であることよ り,

と执いたとき

$$
x=x_{p} / x_{q}
$$

$$
0 \leq|x| \leq 1
$$

と仮定しても一般性は失なわれない.（45）式の仮定の もとに，xの存在する領域を定めれば第 7 図に示すよ5 に，実軸上 0.5 の点を中心に直径 1 なる円の上半分と実 軸によって囲まれた閉領域となる.この領域を円の中心 を通り虚軸に平行な直線で二分し，それぞれ第 I 領域お よび第II領域とする。このとき $x$ が第 I 領域内にあれば (43) 式は 


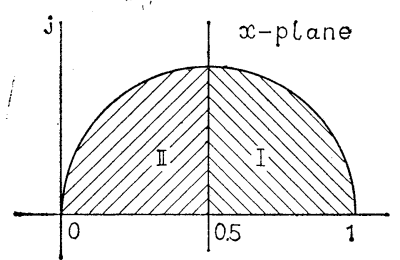

个第 7 図 $\chi$ の在存する領域

第 8 図 Spherical wave moder おける対数振幅括よび位相 の変動の 2 乗平均値 $\rightarrow$

$$
\begin{aligned}
& F\left(x_{p}, x_{q} ; 0\right) \simeq \frac{2}{\sqrt{x_{q}}(1+\sqrt[4]{x})^{2}} \\
& \times \log \frac{2\left(\frac{\sqrt{x_{p}}+\frac{4}{x}}{\sqrt{x_{p}}-\sqrt[4]{x}}\right)}{1+\sqrt{1-\left(\frac{1-\sqrt[4]{x}}{1+\sqrt[4]{\frac{4}{x}}} \frac{\sqrt{x_{p}}+\sqrt[4]{\bar{x}}}{\sqrt{x_{p}}-\sqrt[4]{\bar{x}}}\right)^{2}}}
\end{aligned}
$$

と近似され，第正領域内にある場合には，近似式は

$$
\begin{aligned}
& F\left(x_{p}, x_{q} ; 0\right) \simeq \frac{j 2}{\sqrt{x_{q}}\left(1+\frac{4}{1-\chi}\right)^{2}} \\
& \quad \times \log \frac{2\left(\frac{\sqrt{1-x_{p}}+\sqrt[4]{1-x}}{\sqrt{1-x_{p}}-\sqrt[4]{1-\chi}}\right)}{\left.1+\sqrt{1-\left(\frac{1-\sqrt[4]{1-x}}{1+\sqrt[4]{1-x}} \sqrt{1-x_{p}}+\sqrt[4]{1-\chi}\right.}\right)^{2}}
\end{aligned}
$$

となる、 $x$ の值に応じて (46) あるいは (47) 式を使えば 容易に楕円積分の近似值を求めることができ, さらにそ れを（34）式に代入することにより, 対数振幅沶よび位 相の変動の 2 乗平均值が得られる.な拈，このような近 似による䛊差は高々 $2 \%$ 程度であることが証明される。

つぎに Scattering parameter $D$ が十分小さい場合 特よび十分大きい場合について，フェージングの大きさ を与える近似式を示して拉く、をず Dの小さい Fresnel scattering の範囲では近似式として

$$
\begin{gathered}
\left\langle Q^{2}\right\rangle \simeq \sqrt{\pi} \frac{k^{3} l^{3}}{32}\left\langle\Delta \varepsilon^{2}\right\rangle\left\{\frac{\left(p^{2}-q^{2}\right)^{2}}{80}+\frac{p^{2} q^{2}}{30}\right\} D^{3} \\
\left\langle\theta^{2}\right\rangle \simeq \sqrt{\pi} \frac{k^{3} l^{3}}{16}\left\langle\Delta \varepsilon^{2}\right\rangle D
\end{gathered}
$$

が得られる. (49) 式で与兄られる位相の变動の 2 乗平 均值は Plane wave mode の場合について得られた (41) 式に全く一致している. これに対し (48) 式の対数振幅
の変動は Plane wave mode についての結果である (40) 式にくらべて $1 / 10$ だけ小さくなっていることがわかる.

一力 $D$ が十分大きくなった Fraunhofer scattering の場合は， $x$ は第 7 図の第 1 領域内にあって 1 に近づく。 したがって，このときには(46)式が利用でき，その結果

$$
\left.\begin{array}{l}
\left\langle Q^{2}\right\rangle \\
\left\langle\theta^{2}\right\rangle
\end{array}\right\}=\sqrt{\pi} \frac{k^{3} l^{3}}{32}\left\langle\Delta \varepsilon^{2}\right\rangle D
$$

なる近似式を得る。これは plane waver mode の場合 についての同様な近似式 (42) 式に一致している.

(46) 式女るいは (47) 式を(34) 式に代入して数值計 算した結果を第 8 図に示す.計算は $q=1$ の場合, すな わら誘電率のゆらぎが水平面内に执いて二次元等方性で まる場合について行ない, 垂直方向の異方性の程度を示 すゃは Parameter としてある。な批較のため, 図に は前節で得た Plane wave mode に和ける結果のうち, とくにゆらぎが等方性の場合を破線で示してある.ここ で興味のあることは, 誘電率のゆらぎを等方性と仮定し て計算した Plane wave mode での結果が, これを Spherical wave mode と比較すれば，あたかも異方性 のゆらぎを有する媒質中を伝搬したような特性を示すこ とである。

\section{Bessel 形相関関数の場合について ${ }^{15)}$}

前節までに拈いて，誘電率のゆらぎを統計的に異方性 でめるとし，その相関々数を Gauss と仮定した場合に ついて, フェージングの対数振幅扣よび位相の変動の 2 乗平均值を求めた。 しかしながら Gauss 形相関々数を 仮定することは，数学的取扱いを容易にするという利点 はあっても, それが実際の大気に特ける誘電率のゆらぎ の統計的性質によく合致しているとはいいがたいのであ 
る. Refractometer を使って大気中の誘電率のゆらぎを 実測した最近の報告によれば5,16)，ゆらぎの相関々数は ほぼつぎに示すような Bessel 形であるとされている.

$$
C(r)=\frac{2^{1-\nu}}{\Gamma(\nu)}\left(\frac{r}{l}\right)^{\nu} K_{\nu}\left(\frac{r}{l}\right)
$$

ここにレは相関々数を特長づける 1 つのParameterであ るが, これは地上高とともに一般には減少する傾向にあ る5). そこで本節に抽いては誘電率のゆらぎの相関々数 を，(51）式で与えられる等方性の Bessel 形であるとす る. そして伝搬モードを Plane wave modeとして, フ ェージングの対数振幅および位相の変動の 2 乗平均值を 求め, 相関々数の Parameter レを種々変化させた場合, それがフェージングにぞのような影響を与えるかを見る ことにする.

まず解析を進めるにあたって, Bessel 形相関々数は つぎのように積分表示されることに注目しておく.

$$
\begin{aligned}
& \frac{2^{1-\nu}}{\Gamma(\nu)}\left(\frac{r}{l}\right)^{\nu} K_{\nu}\left(\frac{r}{l}\right) \\
& \quad=\frac{1}{\Gamma(\nu)} \int_{0}^{\infty} S^{\nu-1} \exp \left(-\frac{r^{2}}{4 S l^{2}}-S\right) d S
\end{aligned}
$$

さて，ここで前に返ってフェージングの大きさは (22) 式で与えられるが，そこにふくまれる $I_{1}$ 执よび $I_{2}$ なる 值はそれぞれ (23) 式拉よび (24) 式の相関々数をふく んだ積分によって決定される. そこで (52) 式で与えら れる Bessel 形相関々数の積分表示を (23) 拈よび (24) 式に代入する. その結果

$$
\begin{aligned}
& I_{1}=\frac{1}{\Gamma(\nu)} \int_{0}^{\infty} S^{\nu-1} G_{1}(S) e^{-S} d S \\
& I_{2}=\frac{1}{\Gamma(\nu)} \int_{0}^{\infty} S^{\nu-1} G_{2}(S) e^{-S} d S
\end{aligned}
$$

を得る。ここに

$$
\begin{aligned}
& G_{1}(S)=\int_{\Lambda}^{\Lambda+L} d z \iiint_{-\infty}^{+\infty} d \xi d \eta d \zeta \\
& \exp \left(-\frac{r^{2}}{4 S l^{2}}\right) \Phi_{1}\left[\frac{\zeta(\Lambda+L-2 z)}{k(\Lambda+L)}, \rho\right] \\
& G_{2}(S)=\int_{\Lambda}^{\Lambda+I} d z \iiint_{-\infty}^{+\infty} d \xi d \eta d \zeta \\
& \exp \left(-\frac{r^{2}}{4 S l^{2}}\right) \Phi_{1}\left[\frac{2 z(\Lambda+L-z)}{k(\Lambda+L)}, \rho\right]
\end{aligned}
$$

でありまた

$$
\begin{aligned}
& r^{2}=\xi^{2}+\eta^{2}+\zeta^{2} \\
& \rho^{2}=\xi^{2}+\eta^{2}
\end{aligned}
$$

とおいてある。

(55) 式拉よび (56) 式を見るに，これは相関距離を $2 \sqrt{S}$ 倍にした等方性 Gauss 形相関々数の場合に相当 して和り, Plane wave mode の仮定のもとに, (39) 式 を参照して，ただちにつぎの結果が得られる.

$$
G_{1}(S)=2 \sqrt{\approx L} L l \sqrt{S}
$$

$$
G_{2}(S)=2 \sqrt{\pi} k l^{3} S^{\frac{3}{2}} \tan ^{-1}\left(\begin{array}{c}
L \\
k l^{2} S
\end{array}\right)
$$

(53) 式および (59) 式より容易に

$$
I_{1}=2 \sqrt{\pi} L l \frac{\Gamma\left(\nu+\frac{1}{2}\right)}{\Gamma(\nu)}
$$

が得られる， $I_{2}$ につては (60) 式を(54) 式に代入して

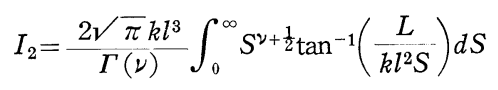

を得る。

ここで害変数 $x$ の関数 $T_{\mu}(x)$ を

$$
T_{\mu}(x)=\frac{1}{\Gamma(\mu) x} \int_{0}^{\infty} S^{\mu} \tan ^{-1}\left(\frac{x}{S}\right) e^{-S} S S \quad(\mu>0)
$$

なる式により定義し，これを使い(62)式を書きかえれば

$$
I_{2}=2 \sqrt{\pi} L l \frac{\Gamma\left(\nu+\frac{1}{2}\right)}{\Gamma(\nu)} T_{\nu+\frac{1}{2}}\left(\frac{L}{k l^{2}}\right)
$$

となる.（61）式拈よび（64）式を(22) 式に代入すれば, 対数振幅括よび位相の変動の 2 乗平均值として

$\left.\begin{array}{l}\left\langle Q^{2}\right\rangle \\ \left\langle\theta^{2}\right\rangle\end{array}\right\}=\frac{\left\langle\Delta \varepsilon^{2}\right\rangle k^{3} l_{0}^{3}}{4 \pi} D\left[1 \mp T_{\nu+\frac{1}{2}}\left(\left\{\frac{\Gamma\left(\nu+\frac{1}{2}\right)}{\Gamma(\nu)}\right\}^{2} D\right)\right]$

を得る.ここに $l_{0}$ は

$$
l_{0}=\int_{0}^{\infty} C(r) d r
$$

で定義されるゆらぎの相関距離であり, Scattering parameter $D$ は

$$
D=\pi L / k l_{0}^{2}
$$

によって与えられる.（65）式によって大気中に打ける 誘電率のゆらぎが Bessel 形相関々数をもつとしたとき, そこを伝搬するマイクロ波の対数振幅と位相の変動の 2 乗平均值が形式的に与えられたことになる.

つぎにフェージングの大きさについての具体的な值を 知るためには, (63) 式で定義される関数 $T_{\mu}(x)$ を数值 計算に適した形にしておく必要がある. そのため, ここ では関数 $T_{\mu}(x)$ を収束の速い級数で表示し，また $x$ が 大きい場合にはこれを漸次展開することにした，しかし 級数表示に関する事項はやや複雑となるので, これは付 録にゆずり（付録一亚参照），ただそれらを利用して行な った数值計算の結果のみを第 9 図に示して抢く.

相関々数の parameter $\nu$ の值としては最も重要と思 われる $1 / 3 ， 1 / 2$ 拈よび 1 をえらんである. 図には等方 性 Gauss 形相関々数を仮定した場合のフェージングの 大きさも合わせて示してある.

図から知られるように誘電率のゆらぎの相関々数を種 種変えても，それによってフェージングの大きさはあま り影響されない，このことから，マイクロ波の対数振幅 
および位相の変動の 2 乗平均値を求める 場合には,ゆらぎの相関々数を数学的に 取扱いの便利な Gauss 形と仮定しても， 大きな誤差にはならないと思われる。 な频付録に示した関数 $T_{\mu}(x)$ の級数表 示より $D$ が小さい場合の近似式として

$$
\begin{aligned}
& \left\langle Q^{2}\right\rangle \simeq \frac{\left(\nu+\frac{1}{2}\right)\left\langle\Delta \varepsilon^{2}\right\rangle k^{3} l_{0}^{3}}{8 \sin \left\{\left(\nu+\frac{1}{2}\right) \pi\right\} \Gamma\left(\nu+\frac{5}{2}\right)} \\
& \times\left\{\frac{\Gamma\left(\nu+\frac{1}{2}\right)}{\Gamma(\nu)}\right\}^{2 \nu+1} D^{\nu+\frac{2}{3}} \\
& \left\langle\theta^{2}\right\rangle \simeq\left\langle\Delta \varepsilon^{2}\right\rangle k^{3} l_{0}{ }^{3} \frac{D}{2 \pi}
\end{aligned}
$$

を得る。また $D$ が大きい場合には $T_{\mu}(x)$ の漸近展開を利用して (70)式が得られる.

$$
\left.\begin{array}{l}
\left\langle Q^{2}\right\rangle \\
\left\langle\theta^{2}\right\rangle
\end{array}\right\}=\left\langle\Delta \varepsilon^{2}\right\rangle k^{3} l_{0}{ }^{3} \frac{D}{4 \pi}
$$

\section{7. 数 值 例}

以上のべてきたことの応用として具体的な数值例をあ 陪ること河る，そのためには，大気中に执ける誘電率 のゆらぎの強さ和よびその相関距離についての数值が必 㴗であるが，ここでは米国での実測例 ${ }^{16)}$ 参照してつぎ のような值をとることにする。すなわら誘電率の強さを

$$
\left\langle\Delta \varepsilon^{2}\right\rangle=4 \times 10^{-12}
$$

またゆらぎの相関距離を

$$
l=80 \mathrm{~m}
$$

とする.（71）式怙よび (72) 式で与兄られる数值から， 《 $\left.\Delta \varepsilon^{2}\right\rangle k^{3} l^{3}$ の值は使用周波数の関数として, 第 1 表の 2 列目に示すように定まる.

さて, 伝搬距離を $40 \mathrm{~km}$ に兄らんで, Spherical wave mode の位相変動を求めて見よ5。それには第 8 図を利 用すればよく, さらに $\left\langle\Delta \varepsilon^{2}\right\rangle k^{3} l^{3}$ の值を考慮して位相変 動の実效值を計算すれば，第 1 表の 3 列目拉よび 4 列目 に示すような結果となる。 ここに得られた程度の位相の 変動は, 高い位相安定度が要求されるような装置に対し ては当然大きな問題となってくると思われる.

第 1 表 位相変動の実効値

\begin{tabular}{c|c|c|c}
\hline \multirow{2}{*}{ 周波数 $(\mathbf{M c})$} & $\left\langle\boldsymbol{\Delta} \varepsilon^{2}\right\rangle(k l)^{\mathbf{3}}$ & \multicolumn{2}{|c}{ 位相変動の実效値 (度) } \\
\cline { 3 - 4 } & & $p=1$ & $p=10$ \\
\hline 30,000 & $5.080 \times 10^{2}$ & 85.22 & 82.36 \\
3,000 & $5.080 \times 10^{-1}$ & 8.551 & 6.995 \\
300 & $5.080 \times 10^{-4}$ & 0.7853 & 0.6263 \\
\hline
\end{tabular}

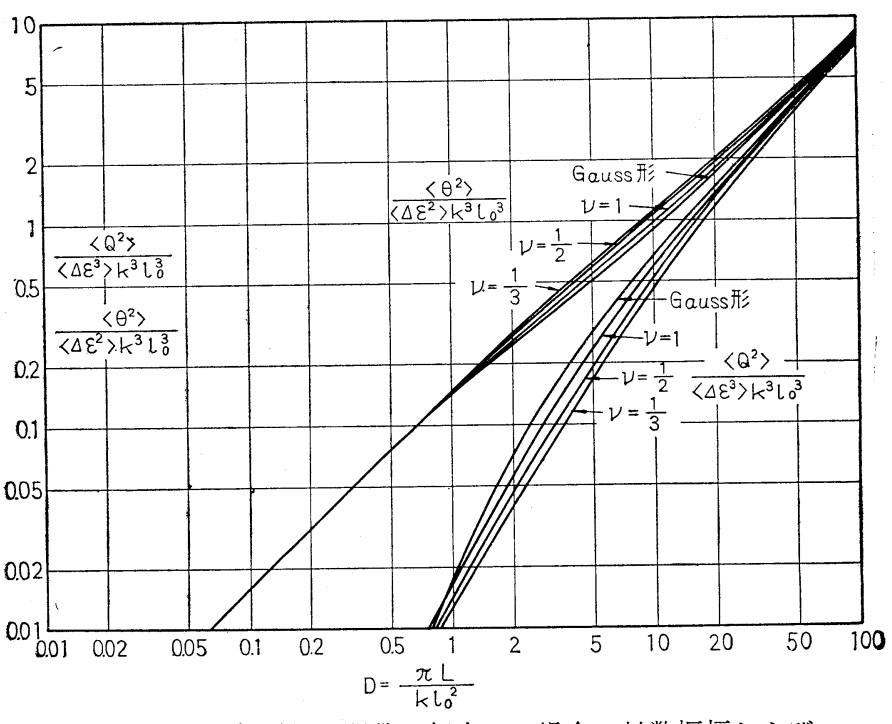

第 9 図 Bessel 形相関関数を仮定した場合の対数振幅怙よび 位相の変動の 2 乗平均値

\section{8. むす び}

大気中を伝搬するマイクロ波のシンチレーション・フ エージングを, 誘電率のゆらぎに結びつけて考察した. とくに誘電率のゆらぎが統計的異方性を有する場合に重 点を置きゆらぎの異方性とシンチレーション・フェー ジングの間の関係について吟味した. 異方性による差異 が最も顕著に現われるのは, Fresnel scattering から Fraunhofer scatering に移る過渡領域に叔いてでめっ て, このことは波動方程式を解いて初めて認められたこ とである.またゆらぎの相関々数を種々変えても，それ がフェージングの大きさにあまり影響しないことを見出 し, これにより対数振幅怙よび位相の変動の大きさを求 める場合には, 数学的に取り扱いの便利な Gauss 形相 関々数を仮定しても大きな誤差とはならないことが結論 できた. 数值例として, 誘電率のゆらぎの実測値をもと にして距離 $40 \mathrm{~km}$ の伝搬路に郝けるマイクロ波の位相 変動を計算したが，その大きさは，高い位相安定度を必 要とする装置に対しては無視しえないじょう乱を与える ことがわかった。

本論で得られた諸結果を, 実際の大気中でのマイクロ 波伝搬に適用するには, 伝搬路は自由空間伝搬路に近い 状態のものが望ましいわけであるが，そのほかに伝搬方 向についても, それが誘電率のゆらぎの等相関面の主軸 に一致していることが仮定されている. このことは, ほ 涪水平な伝搬路では実際に成立っているとしてよいが, 一般の伝搬路については必ずしも満足されることではな い. この方面に理論を拡張するのは今後の問題である. 
本論での考察はフェージングの大きさに関するもので あったが，さらにフェージングの動的特性を表わす相関 関数についても, その基礎を確立して括く必要があろ う. また確率論的な問題としては, シンチレーション・ フェージングを受けた信号の確率分布を，より正確な形 で求めることが残されている ${ }^{12)}$.

\section{付 録-I}

本文 (23) 式の積分を書きかえれば

$$
\begin{aligned}
I_{1} & =\int_{\Lambda}^{\Lambda+I} d z \iiint_{-\infty}^{+\infty} d \xi d \eta d \zeta C(\xi, \eta, \zeta) \\
& \times \frac{k(\Lambda+L)}{2 \pi \zeta(\Lambda+L-2 z)} \sin \left\{\frac{k(\Lambda+L) \rho^{2}}{2 \zeta(\Lambda+L-2 z)}\right\}
\end{aligned}
$$

とそる. 以下において誘電率のゆらぎの座標軸方向の相 関距離をそれぞれ $l_{\xi}, l_{\eta}$ 特よび $l_{\zeta}$ で表わす。

このとき被積分関数中の正弦関数の argument は

$$
\left|\frac{k(\Lambda+L) \rho^{2}}{2 \zeta(\Lambda+L-2 z)}\right| \geq \frac{k \rho^{2}}{2 l_{\zeta}}
$$

なる条件を満足する。このことから

$$
k l_{\xi} \gg \frac{l_{\zeta}}{l_{\xi}}, \quad k l_{\eta} \gg \frac{l_{\zeta}}{l_{\eta}}
$$

が成立つ場合には正弦関数はきわめて激しく振動するこ とがわかる・したがって（A-1) 式の積分には Stationary phase method が適用できて，

$$
\begin{aligned}
I_{1} & =\int_{\Lambda}^{\Lambda+L} d z \int_{-\infty}^{\infty} d \zeta C(0,0, \zeta) \iint_{-\infty}^{+\infty} d \xi d \eta \\
& \times \frac{k(\Lambda+L)}{2 \pi \zeta(\Lambda+L-2 z)} \sin \left\{\frac{k(\Lambda+L) \rho^{2}}{2 \zeta(\Lambda+L-2 z)}\right\}
\end{aligned}
$$

そなる.ここで

$$
\begin{aligned}
\iint_{-\infty}^{+\infty} d \xi d \eta \frac{k(\Lambda+L)}{2 \pi \zeta(\Lambda+L-2 z)} \\
\quad \times \sin \left\{\frac{k(\Lambda+L) \rho^{2}}{2 \zeta(\Lambda+L-2 z)}\right\}=1
\end{aligned}
$$

なることを考慮し，をた相関距離の定義から

$$
\int_{-\infty}^{\infty} C(0,0, \zeta) d \zeta=2 l \zeta
$$

であるから，てだちに次式(A-7)が得られる。

$$
I_{1}=2 L l_{\zeta}
$$

\section{付 録-II}

本文 (43) 式で定義される棈円積分は

$$
u=\sqrt{x_{p} \xi}
$$

なる変数変換により

$$
F\left(x_{p}, x_{q} ; 0\right)=\frac{1}{\sqrt{x_{q}}} \int_{0}^{\overline{\sqrt{x}} \sqrt{x_{p}}} \frac{1}{\sqrt{\left(1-\xi^{2}\right)\left(1-x \xi^{2}\right)}} d \xi
$$

となる. そして母数 $x$ の存在する領域は本文中の第 7 図 に示すごとくである.

まず $x$ が第 7 図の第 I 領域内にあるとして

$$
\sqrt{k}=\frac{1-\frac{4}{\sqrt{x}}}{1+\frac{4}{\sqrt{x}}}
$$

と持き,さらに

$$
\sqrt{k} \eta=\frac{1-\sqrt[4]{x \xi}}{1+\sqrt[4]{x \xi}}
$$

なる変数変換を行なう。このとき（A-9) 式は

$$
\begin{gathered}
F\left(x_{p}, x_{q} ; 0\right)=\frac{2}{\sqrt{x_{q}}\left(1+\frac{4}{\bar{x}}\right)^{2}} \\
\int_{\frac{1}{\sqrt{k}}}^{\frac{1}{\sqrt{k}}}{\sqrt{\overline{x_{p}}-\sqrt[4]{\bar{x}}}}_{\bar{x}} \frac{d \eta}{\sqrt{\left(\eta^{2}-1\right)\left(1-k^{2} \eta^{2}\right)}}
\end{gathered}
$$

となる. ここで

$$
\left|\frac{\sqrt{x_{p}}-\sqrt[4]{x}}{\sqrt{x_{p}}+\frac{4}{x}}\right|<1
$$

なることは容易にわかるが，さらにつぎの不等式が成立 $\supset^{\mathrm{A}-1)}$.

$$
|\sqrt{k}| \leq \tan \frac{\pi}{24}
$$

これより(A-12) 式に拉いて，1飞対して $|k|$ を無視す れば

$$
\begin{aligned}
& F\left(x_{p}, x_{q} ; 0\right) \simeq \frac{2}{\sqrt{x_{q}}\left(1+\frac{4}{\sqrt{x}}\right)^{2}} \\
& \quad \times \log \frac{2\left(\frac{\sqrt{x_{p}}+\frac{4}{\sqrt{x}}}{\sqrt{x_{p}}-\frac{4}{\sqrt{x}}}\right)}{1+\sqrt{1-\left(\frac{1-\frac{4}{\sqrt{x}}}{1+\frac{4}{\sqrt{x}}} \frac{\sqrt{x_{p}}+\frac{4}{\sqrt{x}}}{\sqrt{x_{p}}-\sqrt[4]{\frac{1}{x}}}\right)^{2}}}
\end{aligned}
$$

が得られる，この近似による誤差は (A-14) 式を考慮す

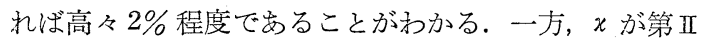
領域内にある場合には, これを

$$
\zeta^{2}=\frac{\xi^{2}}{\xi^{2}-1}
$$

なる変数変換によって，第 I 領域内に移して考旮ればよ $く$, その結果, 次式を得る。

$$
\begin{aligned}
& F\left(x_{p}, x_{q} ; 0\right) \simeq \frac{2 j}{\sqrt{x_{q}}\left(1+\frac{4}{1-x}\right)} \\
& \quad \frac{2\left(\frac{\sqrt{1-x_{p}}+\sqrt[4]{1-x}}{\sqrt{1-x_{p}}-\sqrt[4]{1-x}}\right)}{1+\sqrt{1-\left(\frac{1-\sqrt[4]{1-x}}{1+\frac{4}{1-x}} \frac{\sqrt{1-x_{p}}+\sqrt[4]{1-x}}{\sqrt{1-x_{p}}-\sqrt[4]{1-x}}\right)^{2}}}
\end{aligned}
$$

[参考文献]

A-1） 竹内端三：棈円函数論，岩波全書. 


\section{付 録-III}

本文 (63) 式を部分積分することとより，つぎの溸化 式が得られる.

$$
\begin{aligned}
\frac{T_{\mu}(x)}{\mu} & =\frac{T_{\mu+1}(x)}{\mu+1} \\
& +\frac{\pi x^{\mu}}{\Gamma(\mu+2) \sin (\mu+2) \pi} V_{\mu+2}(2 x ; 0)
\end{aligned}
$$

ここに $V_{\nu}(w, z)$ は 2 変数の Lommel 関数である. (A18）式より容易につぎの級数表示が得られる.

$$
T_{\mu}(x)=\mu \pi x^{\mu} \sum_{n=0}^{\infty} \frac{x^{n} V_{\mu+2+n}(2 x, 0)}{\Gamma(\mu+2+n) \sin (\mu+2+n) \pi}
$$

一方, Lommel 関数については

$$
\begin{aligned}
V_{\nu}(w, 0) & =\cos \left(\frac{w}{2}+\frac{\nu \pi}{2}\right) \\
& +\sum_{m=0}^{\infty} \frac{(-1)^{m}\left(\frac{1}{2} w\right)^{-} \nu^{+2+2 m}}{\Gamma(-\nu+2+2 m+1)}
\end{aligned}
$$

なる級数展開が成立つから，これを(A-19) 式に代入 し,から

$$
\begin{aligned}
\sum_{n=0}^{\infty} \frac{\Gamma(\mu+n-2 m)}{\Gamma(\mu+2+n)} & \multicolumn{2}{r}{\quad 1} \\
\quad=\frac{\pi}{\Gamma(\mu+1) \sin \mu \pi} & (2 m+1) \Gamma(2 m+1-\mu)
\end{aligned}
$$

なる関係式を使光ば, 関数 $T_{\mu}(x)$ の級数表示として

$$
\begin{aligned}
T_{\mu}(x) & =\frac{\pi}{\Gamma(\mu) \sin \mu \pi} \sum_{m=0}^{\infty}(2 m+1) \Gamma(2 m+1-\mu) \\
& -\frac{\mu \pi x^{\mu}}{\sin \mu \pi} \sum_{m=0}^{\infty} \frac{(-x)^{m} \cos \left(x+\frac{\mu+m}{2} \pi\right)}{\Gamma(\mu+2+m)}(\mathrm{A}-22)
\end{aligned}
$$

が得られる。

次数 $\mu$ が整数の場合は（A-22）式は不定形となるが， 極限の意味で

$$
\begin{aligned}
T_{n}(x) & =\frac{\pi}{2} \frac{n}{x}+\frac{1}{\Gamma(n)} \sum_{m \leq \frac{n-1}{2}}^{m \leq \frac{n-1}{2}} \frac{\Gamma(n-2 m)}{2 m+1} x^{2 m} \\
& -n \sum_{m=0}^{m} \frac{(-1)^{m} x^{2 m}}{(2 m+1) \Gamma(2 m+2)} \\
& -(\sin x \operatorname{Ci} x-\cos x \sin x) \frac{n}{x} \sum_{m=0}^{m \leq n / 2} \frac{(-1)^{m} x^{2 m}}{\Gamma(2 m+1)} \\
& +(\cos x \operatorname{Ci} x+\sin x \sin x) \frac{n}{x} \sum_{m=0}^{m \leq \frac{n-1}{2}} \frac{(-1)^{m} x^{2 m+1}}{\Gamma(2 m+2)}
\end{aligned}
$$

が成立つ.

ここに si $x$ 特よびCi $x$ はとれぞれ正弦積分就よび余 弦積分であって, 次式で定義される.

$$
\begin{aligned}
\text { si } x & =-\int_{x}^{\infty} \frac{\sin t}{t} d t \\
\text { Ci } x & =-\int_{x}^{\infty} \frac{\cos t}{t} d t
\end{aligned}
$$

関数 $T_{\mu}(x)$ の漸近展開を求めるには

$$
\tan ^{-1}\left(\frac{t}{S}\right)=\frac{\pi}{2}-\sum_{n=0}^{\infty} \frac{(-)^{n}}{2 n+1}\left(\frac{S}{x}\right)^{2 n+1}
$$

なる級数展開を利用して項別積分すればよく，との結果

$$
\begin{aligned}
T_{\mu}(x) & \sim \frac{1}{\Gamma(\mu) x}\left[\frac{\pi}{2} \Gamma(\mu+\mathrm{I})\right. \\
& -\sum_{n=0}^{\infty} \frac{(-1)^{n} \Gamma(2 n+\mu+2)}{(2 n+1) x^{2 n+1}}
\end{aligned}
$$

となる。

\section{[参考文献]}

1) R.B. Muchmore and A.D. Wheelon : Line-of-sight propagation phenomena, I., Proc. IRE, 43 (1955), 1437 :

2) A. D. Wheelon and R.B Muchmore: Line-of-sight propagation phenomena, II., Proc. IRE, 43 (1955), 1450.

3) L.A.Chernov: Wave propagation in a random medium, Mc Graw-Hill, (1960).

4) B.M. Fannin : Line-of-sight wave propagation in a randomly inhomogeneous medium, IRE Trans, PGA P, AP-4, (1956), 661.

5) A.W.Straition, A.P.Deam and G.B.Walker : Spectra of Radio Refractive index between ground level and 5000 feet above ground, IRE Trans, PGAP, AP-10(1962) 732.

6) R.Bolgiano, Jr. : A theory of wavelength dependence in ultrahigh frequency transhorizon propagation based on meteorological considerations, J. Res. NBS; $64 \mathrm{D}(1960), 231$.

7) J.W. Herbstreit and M.C. Thompson : Measurements of the phase of radio waves received transmission paths with electrical lengths varying as a result of atomospheric turbulence, Proc. IRE, 43 (1955), 1391.

8) C.W.Tolbert and A.W. Straiton: Attenuation and fluctuation of millimeter radio waves, IRE Nat. Conv: Record, Pt. I, (1957) 12.

9) K.C. Yeh : Propagation of spherical waves through an ionospheric containing anistropic irregularities: J. Res. NBS, 66 D (1962), 621.

10) H.G.Booker : The use of radio stars to study irregular refraction of radio waves in the ionosphere, Proc. IRE, 46 (1958), 298.

11) K.A. Norton, L.E. Vogler, W. V. Mansfield and P. J. Short: The probability distribution of the amplitude. of a constant vector plus a Rayleigh-distributed vector, Proc. IRE, 43 (1955), 1354.

12) P.Beckmann : Statistical distribution of the amplitude and phase of a multiply scattered fleld, J: Res. NBS; $66 \mathbf{D}$ (1962), 231.

13）米山務，虫明康人：大気中の異方性渦乱のマイクロ波伝播に及ぼす 影響 (その一), 東北大学伝送工学研究会資料 (1961).

14）米山務, 虫明康人：見透し内マイクロ波伝搬に於湆るシンチレーシ ョン・フェーデングについて (その三), 東北大学伝送工学研究会資 料 (1962).

15）米山務, 虫明康人：見透し内マイクロ波伝搬に於状るフェーデング に関する研究 (その二), 東北大学伝送工学研究会資料 (1962).

16) E.E. Gossard : Power spectra of temperature, humidity and rafractive index from aircraft and tethered balloon measurements, IRE Trans. PGAP, AP-8; (1960), 186. 